Article

\title{
Hydrological Effectiveness of an Extensive Green Roof in Mediterranean Climate
}

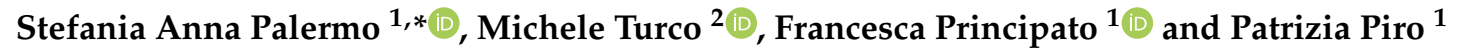 \\ 1 Department of Civil Engineering, University of Calabria, 87036 Rende (CS), Italy \\ 2 Department of Environmental and Chemical Engineering, University of Calabria, 87036 Rende (CS), Italy \\ * Correspondence: stefania.palermo@unical.it
}

Received: 16 May 2019; Accepted: 2 July 2019; Published: 4 July 2019

\begin{abstract}
In urban water management, green roofs provide a sustainable solution for flood risk mitigation. Numerous studies have investigated green roof hydrologic effectiveness and the parameters that influence their operation; many have been conducted on the pilot scale, whereas only some of these have been executed on full-scale rooftop installations. Several models have been developed, but only a few have investigated the influence of green roof physical parameters on performance. From this broader context, this paper presents the results of a monitoring analysis of an extensive green roof located at the University of Calabria, Italy, in the Mediterranean climate region. To obtain this goal, the subsurface runoff coefficient, peak flow reduction, peak flow lag-time, and time to the start of runoff were evaluated at an event scale by considering a set of data collected between October 2015 and September 2016 consisting of 62 storm events. The mean value of subsurface runoff was $32.0 \%$ when considering the whole dataset, and $50.4 \%$ for 35 rainfall events (principally major than $8.0 \mathrm{~mm}$ ); these results indicate the good hydraulic performance of this specific green roof in a Mediterranean climate, which is in agreement with other studies. A modeling approach was used to evaluate the influence of the substrate depth on green roof retention. The soil hydraulics features were first measured using a simplified evaporation method, and then modeled using HYDRUS-1D software (PC-Progress s.r.o., Prague, Czech Republic) by considering different values of soil depth $(6 \mathrm{~cm}, 9 \mathrm{~cm}, 12 \mathrm{~cm}$, and $15 \mathrm{~cm})$ for six months under Mediterranean climate conditions. The results showed how the specific soil substrate was able to achieve a runoff volume reduction ranging from $22 \%$ to $24 \%$ by increasing the soil depth.
\end{abstract}

Keywords: green roof; rainfall runoff; subsurface runoff coefficient; retention; soil depth; HYDRUS-1D model; urban hydrology

\section{Introduction}

The combined effect of climate change and land-use alterations, due to ongoing urbanization, produces several environmentally adverse effects. The constant loss of natural areas, which significantly affects the natural hydrological cycle, and the increase in the frequency of extreme weather events have resulted in a considerable increase in runoff volumes that overload the drainage systems and produce floods [1-4].

In this scenario, the use of sustainable solutions as an alternative to conventional techniques has become a general goal of urban water management. To move in this sustainable direction, low impact developments (LIDs) such as green roofs (GRs) are a possible eco-solution that contributes to restoring the pre-development natural hydrological response [5-8].

GRs, by exploiting otherwise unused spaces, are particularly beneficial in densely built urban areas [9]. They represent a source of storm water runoff mitigation by reducing the total runoff volume, peak flow rate, and delaying peak discharge time into the combined sewer systems [10,11]. GRs, which 
incorporate both the natural environment and engineered systems, offer a wide range of other benefits, including an enhancement of water quality, reduction in the building energy demand, attenuation of urban heat islands, decrease in air pollution and noise levels in urban spaces, increase in the building's aesthetic value, and wildlife and biodiversity growth [12-17].

Many studies agree on the classification of GRs into two main categories: extensive and intensive, which differ from each other regarding the depth of soil layer and vegetation. Generally, extensive GRs have a thin soil layer of less than approximately $15 \mathrm{~cm}$, whereas intensive soil layers exceed this value; shallow rooting and drought-resistant plants are used for the extensive GR, whereas deeper rooting plants are used for the intensive GRs. Therefore, due to its characteristics, the extensive GR is lighter, cheaper, and requires less maintenance than the intensive one [18-20].

Several studies have analyzed GRs retention performance worldwide; many of these have been conducted on a pilot scale, generally consisting of different test beds or similar modules [11,18,19]; others have been conducted on a full-scale rooftop $[10,20,21]$. However, not all of these have analyzed the GR behavior for a continuous monitoring period, evaluating each parameter on an event scale.

The hydraulic behavior of GRs has also been analyzed from a modeling point of view. Numerical models have been developed using software such as the Environmental Protection Agency (EPA)'s Storm Water Management Model (SWMM) [19,22-24], Soil, Water, Atmosphere, and Plant (SWAP) model [25], and HYDRUS model [26-29].

From the analysis of these studies, some indicators (runoff volume reduction, peak flow reduction, peak flow lag-time, etc.) have been used to estimate GR hydraulic effectiveness. Another useful lumped parameter that is crucial for designing purposes is the subsurface runoff coefficient (SRC), which is calculated as the ratio between the total runoff depth delivered from the GR and the total rainfall depth, i.e., the inverse value of the GR retention capacity. From a literature review completed by Garofalo et al. [30], the SRC presented a large variability in mean value, ranging from 0.30 to 0.90 . This wide range can be explained by analyzing, for each study, the climate conditions of the GR site, the GR's size (full-scale or pilot system), period of data analysis, the time step resolution, and the hydraulic and physical features.

Factors that typically influence GR water retention capacity can be grouped in two main categories: weather conditions (length of the antecedent dry weather period, season/climate, characteristics of rainfall event) and the GR's physical features (number of layers and materials, substrate depth, its hydraulic characteristics, type of vegetation, percentage of roof covered, roof geometry, and green roof age). Being unable to intervene in the weather conditions of the site where the installation is located, the choice of the physical characteristics of the substrate is crucial. In this regard, many studies have observed that the hydraulic behavior of a GR is influenced by the substrate depth and type [31-33]. Some of these studies were conducted in the laboratory by considering constant rainfall data and not real data recorded by a rain gauge, whereas others considered the results of modeling simulations based on literature hydraulic soil properties and not real substrate hydraulic properties.

From this broader context, the first objective of this study was to present the field hydrological monitoring results of a specific extensive GR that has been installed at the University of Calabria, Italy, in a Mediterranean climate. To complete this analysis, first, one year of rainfall data (October 2015 to September 2016) recorded by a rain gauge located on the experimental site was selected. Secondly, the corresponding runoff from the GR was evaluated and compared with the runoff from an impervious roof, which was located at the same site. Thirdly, to analyze the green roof's hydraulic efficiency, the response in terms of the SRC, peak flow reduction (PFR), peak flow lag-time (PFL), and time to start of runoff (TSR) were determined on an event scale. The second objective of the study was to evaluate the influence of the soil depth on the retention capacity of a substrate soil for an extensive green roof in Mediterranean climate by considering the measured soil hydraulic properties and varying the thickness (from 9 to $15 \mathrm{~cm}$ ) by means of the HYDRUS-1D model. 


\section{Materials and Methods}

\subsection{Experimental Site}

The experimental green roof (Figure 1) was built in 2012 on the terrace of the Department of Mechanical, Energy and Management Engineering (DIMEG), at the University of Calabria, Italy, located $221 \mathrm{~m}$ above sea level in the Vermicelli Catchment. The University is in the south of Italy in the vicinity of Cosenza $\left(39^{\circ} 18^{\prime} \mathrm{N} 16^{\circ} 15^{\prime} \mathrm{E}\right)$, under a Mediterranean climate condition, which is characterized by an average annual precipitation of $881.2 \mathrm{~mm} /$ year and a mean annual temperature of $15.5^{\circ} \mathrm{C}$ [27].

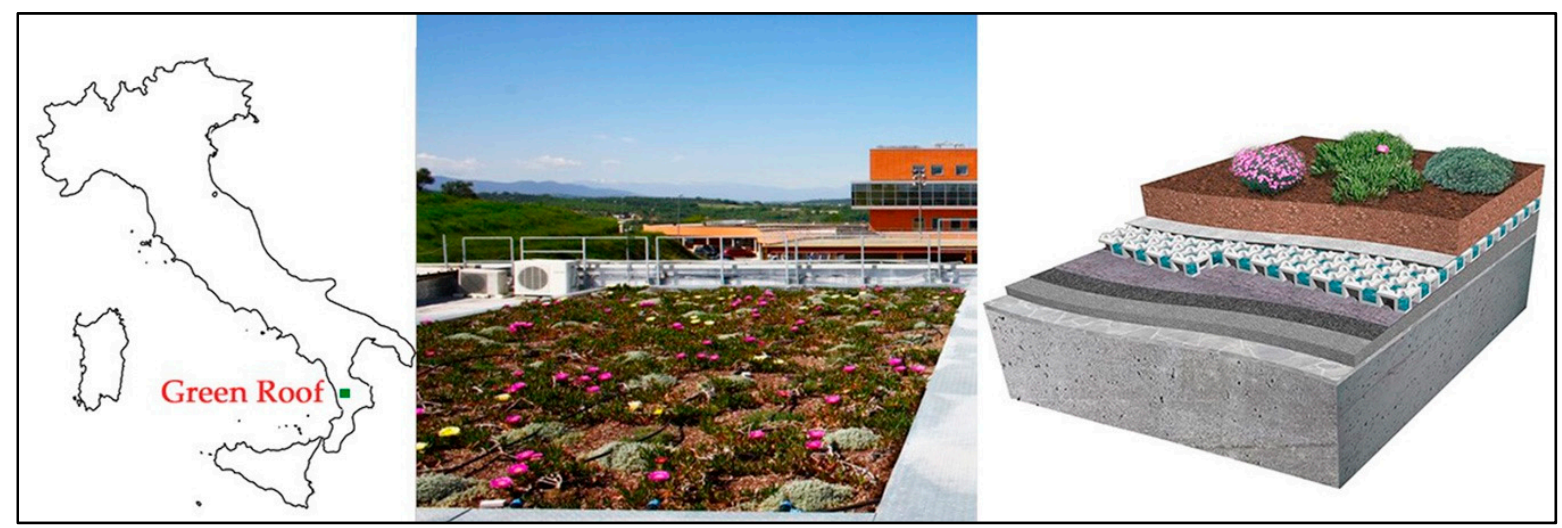

Figure 1. The experimental green roof (GR) located at the University of Calabria, Italy. A map of Italy, with the location of the green roof (left), the GR experimental site (middle), and an axonometric detail stratigraphy (right). All the figures were captured or created by the Urban Hydraulic and Hydrology Laboratory, University of Calabria, Italy.

The green roof (GR) was built according to Italian regulation UNI 11235, and from top to bottom consisted of: (1) a surface layer, vegetated with three native Mediterranean species; (2) a commercial soil substrate, called "Terra Mediterranea" (Harpo spa, Trieste, Italy), with a maximum depth of $8 \mathrm{~cm}$ composed of a mineral terrain; (3) a permeable geotextile with a weight of $105 \mathrm{~g} / \mathrm{m}^{2}$ to prevent fine soil particles from moving into the underlying layers; (4) a drainage layer in polystyrene foam with a water storage capacity of $11 \mathrm{~L} / \mathrm{m}^{2}$ and a drainage capacity of $0.46 \mathrm{~L} \cdot \mathrm{s}^{-1} \mathrm{~m}^{-2}$; (5) an anti-root layer consisting of a waterproof bituminous membrane with an anti-root additive, specific for green roof installation; and (6) an additional recovery waterproof membrane in elastobituminous membrane. In detail, as discussed in depth by Brunetti et al. [27], the soil substrate consists of a mineral soil with $74 \%$ gravel, $22 \%$ sand, and $4 \%$ silt and clay; it presents a measured bulk density of $0.86 \mathrm{~g} \cdot \mathrm{cm}^{-3}$ and $8 \%$ organic matter, which was determined in the laboratory using the Walkley-Black method. Among the three native Mediterranean species, two are herbaceous plants that are suited for well-drained soils (Dianthus gratianopolitanus and Cerastium tomentosum), and one is a succulent plant (Carpobrotus edulis), which is characterized by a high drought tolerance. More detail on the specific soil substrate hydraulic properties are reported in the results section, where the measurements recorded in the laboratory are provided.

To evaluate the hydraulic efficiency of this specific stratigraphy, the outflow collected from the GR, which is characterized by an area of $50 \mathrm{~m}^{2}$ and a slope of $1 \%$, was compared with that discharged by an impervious roof (IR) located on the same site, which presented an area of $40 \mathrm{~m}^{2}$. The different areas of the GR and IR were considered during the outflow comparison analysis.

The GR water supply is guaranteed only by reusing the green roof's outflow, which was collected in a specific storage tank and distributed through a drip irrigation system. This irrigation system is activated during drought periods, generally occurring in summer when the precipitation volume for the specific climate condition is low and very high temperatures are recorded in accordance with low 
values of soil moisture measured in the soil substrate. By analyzing the whole dataset, the irrigation, actioned only during the driest days, did not affect the runoff results.

Rainfall depth was measured every minute using a tipping bucket rain gauge with a resolution of $0.254 \mathrm{~mm}$, which was located on the roof. The outflow rates were collected by a flow meter device that was installed at the base of the building, consisting of a vertically developed system, formed by a polyvinyl chloride (PVC) pipe with a sharp-crested weir [34]. The water level in the device was measured by a pressure transducer (Ge Druck PTX1830, GE Measurement \& Control Solutions, Groby Leicester, UK), with a measurement range of $75 \mathrm{~cm}$ and an accuracy of $0.1 \%$ of the full scale, and was continuously recorded in the SQLITE database system with a resolution of $1 \mathrm{~min}$.

\subsection{Data Analysis}

For this study, rainfall and runoff data with one-minute time resolution that were recorded at the experimental site between October 2015 and September 2016 were considered.

In the first phase, from all the data collected, only the events with a precipitation depth greater than $2 \mathrm{~mm}$ were selected. This assumption was supported by an analysis of the recorded rainfall events. We found that the 51 events (total volume around $28 \mathrm{~mm}$ ) with rainfall depths less than $2 \mathrm{~mm}$ are unlikely to produce runoff volume for the specific site, confirming the assumption of Voyde et al. [10]. Individual events were also defined as being separated by continuous dry periods of at least six hours $[10,11,35]$.

To consider the hydrological features of each storm event, the precipitation depth (PD), rainfall duration (D), rainfall intensity (i), antecedent dry weather period (ADWP, defined as the dry weather period between two independent rainfall events), and event return period ( $R P$, defined as the average recurrence interval between events equaling or exceeding a specific magnitude [36]), were evaluated at the event scale. To use a more rigorously probabilistic method, the characteristics of the selected storm events were evaluated by considering the local precipitation pattern. For the evaluation of the return period (RP) event, the experimental rainfall events were compared with the historical records obtained from the Regional Agency Prevention Environment in Calabria Region, Italy (ARPACAL) [37]. To consider all the rainfall events here with a duration of more than one day, the intensity-duration-frequency (IDF) relationships were computed by analyzing the historical records of the annual maximum series for rainfall durations of 1, 3, 6, 12, and 24 hours (1923-2012) and for rainfall durations of 1, 2, 3, 4, and 5 days (1935-1999) according to data from the rain gauge station in Cosenza.

In the second phase, for each selected rainfall event and by using the data collected from the flux meter devices, the corresponding total outflow rate in terms of runoff depth (RD) from the GR and IR were evaluated. We chose to show the results in terms of runoff depth $(\mathrm{mm})$ and not in terms of runoff flow (L/s or $\mathrm{m}^{3} / \mathrm{s}$ ) to obtain two comparable values, despite the two different areas of the GR and IR.

Finally, in order to determine the green roof (GR) hydraulic effectiveness, the precipitation hyetographs and corresponding hydrographs of GR and impervious roof (IR) on an event scale were analyzed and the hydrological indicators, reported below, were estimated.

(1) Subsurface runoff coefficient $(S R C)$ was expressed as a percentage ratio between the total RD from GR $\left(R D_{G R}\right)$ and the total precipitation depth $(P D)$ :

$$
\operatorname{SRC}(\%)=\frac{R D_{G R}}{P D} \times 100
$$

(2) Peak flow reduction (PFR) was calculated as the percentage difference between the hydrographs peak of the IR $\left(P F_{I R}\right)$ and hydrographs peak of the GR $\left(P F_{G R}\right)$ :

$$
\operatorname{PFR}(\%)=\frac{P F_{I R}-P F_{G R}}{P F_{I R}} \times 100
$$


(3) Peak flow lag-time (PFL) was determined as the time difference between the peak of precipitation hyetograph $\left(t_{P}\right)$ and the peak of GR hydrograph $\left(t_{P_{G R}}\right)$ :

$$
\operatorname{PFL}(\min )=t_{P_{G R}}-t_{P}
$$

(4) Time to start of runoff (TSR) was evaluated, according to Stovin et al. [11], as the time difference between the start of rainfall $\left(t_{0}\right)$ and the time at which the total runoff exceeded $0.01 \mathrm{~mm}$ $\left(t_{R D>0.01 \mathrm{~mm}}\right)$ :

$$
\operatorname{TSR}(\min )=t_{R D>0.01 \mathrm{~mm}}-t_{0}
$$

\subsection{Soil hydraulic Properties}

To evaluate the influence of the substrate depth on green roof retention capacity, a six-month dataset (January 2016 to June 2016) was selected from a weather station that measured the precipitation, velocity and direction of wind, air humidity, air temperature, atmospheric pressure, and global solar radiation. The weather station is located at the University of Calabria, next to the experimental site (the Green Roof) cited in this work. Data from the station were collected online and were processed and stored in an SQL database. Reference evapotranspiration was calculated using the Penman-Monteith equation [38]. An average value of albedo of 0.23 was assumed considering that the albedo for vegetated areas was 0.23 in a similar study conducted on a green roof [39].

In order to assess the hydrological response of the green roof by variating the soil substrate depth using the HYDRUS model, the hydraulic properties of the soil materials were investigated.

There are many methods to assess the hydraulic properties of soils in different conditions [40,41]. Among these, the simplified evaporation method [42] is one of the most popular. This method is based on measuring both soil moisture and pressure head during a soil drying cycle under the effect of evaporation. The method was developed by Wind [43], who introduced an iterative graphical procedure to estimate, first, the water retention curve from the average soil moisture and pressure head readings, and to define hydraulic conductivities from measured pressure head profile and variations in the water content distribution. Afterwards, several authors proposed simplifications to this method [44-46].

In this work, the hydraulic properties of the soil substrates were measured in the Urban Hydraulics and Hydrology Laboratory, University of Calabria, Italy using a simplified evaporation method proposed by Schindler et al. $[45,46]$ using the HYPROP ${ }^{\circledR}$ device (METER Group AG, Munich, Germany) [47]. With this method, two tensiometers are placed at two depths of a soil sample sitting in a sample ring. The plane in the middle between the two tensiometers is identical to the horizontal symmetry plane of the column. The sample is saturated with water, basally closed, and set on a balance. The soil surface is open to the ambient atmosphere so that the soil water can evaporate. HYPROP ${ }^{\circledR}$ (METER Group AG, Munich, Germany) measures the water tension in two horizons of the soil sample over the evaporation process by means of two vertical tension shafts. The changing mass of the sample over time is assessed by weighing. The medial water content is calculated based on the mass change. This results in one measuring value per point in time for the retention curve.

The soil substrate of the green roof for the laboratory analysis was packed using a stainless-steel sampling ring with a volume of $250 \mathrm{~mL}$. Then, the soil sample was saturated from the bottom before starting the evaporation test. The measurement unit and the tensiometers were degassed using a vacuum pump to reduce the potential nucleation sites in the demineralized water. At the end of the experiment, the sample was placed in an oven at $105^{\circ} \mathrm{C}$ for $24 \mathrm{~h}$; then, the dry weight was measured. For a complete description of the system, please refer to the UMS [47].

The numerical optimization procedure, HYPROP-FIT [48], was used to simultaneously fit the retention and hydraulic conductivity functions to the experimental data obtained using the evaporation method. Fitting was accomplished using a non-linear optimization algorithm that minimizes the sum of the weighted squared residuals between model predictions and measurements. 
The unimodal van Genuchten-Mualem model [49] was evaluated for the description of soil hydraulic properties:

$$
\begin{gathered}
\Theta= \begin{cases}\frac{1}{\left(1+(\alpha|h|)^{n}\right)^{m}} & \text { if } h \leq 0 \\
1 & \text { if } h>0\end{cases} \\
\Theta=\frac{\theta-\theta_{r}}{\theta_{s}-\theta_{r}} \\
K= \begin{cases}K_{s} \Theta^{L}\left[\left(1-\left(1-\Theta^{\frac{1}{m}}\right)\right)^{m}\right]^{2} & \text { if } h<0 \\
K_{s} & \text { if } h>0\end{cases} \\
m=1-\frac{1}{n}
\end{gathered}
$$

where $\Theta$ is the effective saturation; $\alpha$ is a parameter related to the inverse of the air-entry pressure head $\left(\mathrm{L}^{-1}\right) ; \theta_{s}$ and $\theta_{r}$ are the saturated and residual water contents, respectively $(-) ; n$ and $m$ are pore-size distribution indices; $K_{s}$ is the saturated hydraulic conductivity $\left(\mathrm{L} \cdot \mathrm{T}^{-1}\right)$; and $L$ is the tortuosity and pore-connectivity parameter.

\subsection{Simulation Procedure}

Based on the hydraulic properties measured by the simplified evaporation method proposed by Schindler et al. [45,46] using the HYPROP ${ }^{\circledR}$ device (METER Group AG, Munich, Germany) [47], we analyzed the runoff volume from a specific substrate for an extensive green roof by considering increasing values of soil depth using the HYDRUS-1D model. In detail, the cumulative runoff volume from the green roof, in response to a continuous period of six months of rainfall events, was evaluated by varying the depth of the soil from time to time, not exceeding the maximum soil thickness of $15 \mathrm{~cm}$ generally attributed to an extensive green roof $(6 \mathrm{~cm}, 9 \mathrm{~cm}, 12 \mathrm{~cm}$, and $15 \mathrm{~cm})$.

To run a simulation by varying the soil substrate, the HYDRUS-1D model [50] was used. HYDRUS-1D is a one-dimensional finite element model that is used for simulating the movement of water, heat, and multiple solutes in variably saturated porous media. HYDRUS-1D implements multiple uniform (single-porosity) and nonequilibrium (dual-porosity and dual-permeability) water flow models [50].

The studied green roof was interpreted as a one-dimensional, single-porosity, porous medium system, which could be described by the Richards equation in the following form:

$$
\frac{\partial \theta}{\partial z}=\frac{\partial}{\partial z}\left[K(h) \frac{\partial h}{\partial z}+1\right]-S
$$

where $\theta$ is the volumetric water content, $h$ is the soil water pressure head $(\mathrm{L}), K(h)$ is the unsaturated hydraulic conductivity $\left(\mathrm{LT}^{-1}\right), z$ is the soil depth $(\mathrm{L})$, and $S$ is a sink term $\left(\mathrm{L}^{3} \mathrm{~L}^{-3} \mathrm{~T}^{-1}\right)$, which is defined as a volume of water removed from a unit volume of soil per unit of time due to plant water uptake. Feddes et al. [51] defined $S$ as:

$$
S(h)=a(h) \times S_{p}
$$

where $a(h)$ is a dimensionless water stress response function that depends on the soil pressure head $h$ and has a range of values between $0-1$, and $S_{p}$ is the potential root water uptake rate.

Feddes et al. [51] proposed a water stress response function, in which water uptake is assumed to be zero close to soil saturation and for pressure heads higher than the wilting point. Water uptake is assumed to be optimal between two specific pressure heads, which depend on a particular plant. Feddes parameters were assumed according to the HYDRUS database considering the vegetation as grass. 


\subsection{Numerical Domain and Boundary Conditions}

The numerical domain representing the stratigraphy of the green roof consisted of one layer. An atmospheric boundary condition was applied at the soil surface using the precipitation and meteorological conditions measured. A seepage face boundary condition was specified at the bottom of the layer. A seepage face boundary acts as a zero-pressure head boundary when the bottom boundary node is saturated, and as a no-flux boundary when it is unsaturated.

The initial pressure head was assumed to be constant in the entire domain and was set to $-100 \mathrm{~cm}$.

\section{Results and Discussion}

\subsection{Rainfall Events}

The whole studied period was characterized by 62 rainy events and one snowy event (19 January 2016), which was not considered in this study (Table 1), for a total precipitation depth (PD) of $1256.3 \mathrm{~mm}$ ranging from $2.0 \mathrm{~mm}$ to $120.1 \mathrm{~mm}$ with a mean value of $20.3 \mathrm{~mm}$. For the whole dataset and the specific climate conditions, more than half $(51.6 \%)$ of the rainfall events had a precipitation depth less than $10 \mathrm{~mm}$, while $24.2 \%$ had a precipitation depth between $10-30 \mathrm{~mm}, 16.1 \%$ had a precipitation depth between $30-50 \mathrm{~mm}, 3.2 \%$ had a precipitation depth between $50-70 \mathrm{~mm}, 1.6 \%$ (one event) had a precipitation depth between 70-90 $\mathrm{mm}$, one event had a precipitation depth between 90-110 $\mathrm{mm}$, and one had a precipitation depth greater than $110 \mathrm{~mm}$. Our analysis is representative of the specific precipitation pattern where the experimental site is located, and therefore is affected by the Mediterranean climate condition characterized by hot and dry summers and cool and wet winters [30].

Table 1. Hydrological characteristics of each rainfall event collected from October 2015 to September 2016 on the experimental site. PD: precipitation depth, D: rainfall duration, Mean i: mean rainfall intensity, Max i: maximum rainfall intensity, ADWP: antecedent dry weather period, and RP: return period.

\begin{tabular}{|c|c|c|c|c|c|c|c|}
\hline No. & Date & PD & D & Mean i & Maxi & ADWP & $\mathbf{R P}$ \\
\hline & (dd/mm/yyyy; hh:mm) & $(\mathrm{mm})$ & (hh:mm) & $(\mathrm{mm} / \mathrm{h})$ & $(\mathrm{mm} / \mathrm{h})$ & (hh:mm:ss) & (years) \\
\hline 1 & 07/10/2015; 07:47 & 42.2 & $15: 05$ & 2.8 & 121.9 & - & $<1$ \\
\hline 2 & 09/10/2015; 19:21 & 24.1 & $16: 32$ & 1.5 & 167.6 & $43: 40$ & $<1$ \\
\hline 3 & $10 / 10 / 2015 ; 23: 25$ & 48.3 & $17: 11$ & 2.8 & 106.7 & $11: 33$ & $<1$ \\
\hline 4 & $15 / 10 / 2015 ; 08: 01$ & 6.4 & $04: 24$ & 1.4 & 15.2 & $90: 45$ & $<1$ \\
\hline 5 & $21 / 10 / 2015 ; 14: 51$ & 120.1 & $42: 55$ & 2.8 & 45.7 & $146: 25$ & $<20$ \\
\hline 6 & $29 / 10 / 2015 ; 13: 10$ & 63.3 & $35: 32$ & 1.8 & 61.0 & $147: 25$ & $<2$ \\
\hline 7 & $21 / 11 / 2015 ; 23: 26$ & 37.1 & $10: 37$ & 3.5 & 30.5 & $526: 45$ & $<1$ \\
\hline 8 & $23 / 11 / 2015 ; 16: 30$ & 13.0 & 04:19 & 3.0 & 15.2 & $30: 28$ & $<1$ \\
\hline 9 & $24 / 11 / 2015 ; 17: 24$ & 97.3 & $61: 31$ & 1.6 & 76.2 & $20: 34$ & $<3$ \\
\hline 10 & 28/11/2015; 08:49 & 2.8 & $01: 53$ & 1.5 & 15.2 & $25: 54$ & $<1$ \\
\hline 11 & $10 / 12 / 2015 ; 13: 05$ & 8.4 & $02: 48$ & 3.0 & 15.2 & 290:22 & $<1$ \\
\hline 12 & 03/01/2016; 06:04 & 66.3 & $36: 28$ & 1.8 & 76.2 & $566: 10$ & $<2$ \\
\hline 13 & 05/01/2016; 02:51 & 3.3 & $08: 15$ & 0.4 & 30.5 & 08:19 & $<1$ \\
\hline 14 & $06 / 01 / 2016 ; 05: 45$ & 24.6 & 24:08 & 1.0 & 30.5 & $18: 37$ & $<1$ \\
\hline 15 & 07/01/2016; 19:36 & 9.9 & 08:58 & 1.1 & 15.2 & $13: 43$ & $<1$ \\
\hline 16 & $12 / 01 / 2016 ; 19: 02$ & 6.1 & $08: 43$ & 0.7 & 30.5 & $110: 28$ & $<1$ \\
\hline 17 & $15 / 01 / 2016 ; 21: 39$ & 24.9 & $25: 51$ & 1.0 & 15.2 & $58: 22$ & $<1$ \\
\hline 18 & 11/02/2016; 08:01 & 23.4 & $04: 54$ & 4.8 & 30.5 & 519:58 & $<1$ \\
\hline 19 & $12 / 02 / 2016 ; 06: 25$ & 18.8 & 07:07 & 2.6 & 45.7 & $17: 30$ & $<1$ \\
\hline 20 & $12 / 02 / 2016 ; 23: 22$ & 74.9 & $35: 24$ & 2.1 & 76.2 & 09:49 & $<3$ \\
\hline 21 & $18 / 02 / 2016 ; 05: 26$ & 45.2 & $18: 25$ & 2.5 & 45.7 & $90: 40$ & $<1$ \\
\hline 22 & $20 / 02 / 2016 ; 12: 15$ & 4.6 & $00: 48$ & 5.7 & 30.5 & $36: 24$ & $<1$ \\
\hline 23 & $23 / 02 / 2016 ; 22: 11$ & 3.1 & $02: 55$ & 1.0 & 15.2 & $81: 07$ & $<1$ \\
\hline 24 & $26 / 02 / 2016 ; 03: 52$ & 10.9 & $19: 30$ & 0.6 & 30.5 & $50: 46$ & $<1$ \\
\hline
\end{tabular}


Table 1. Cont.

\begin{tabular}{|c|c|c|c|c|c|c|c|}
\hline No. & Date & PD & $\mathbf{D}$ & Mean i & Maxi & ADWP & $\mathbf{R P}$ \\
\hline & (dd/mm/yyyy; hh:mm) & $(\mathrm{mm})$ & (hh:mm) & $(\mathrm{mm} / \mathrm{h})$ & $(\mathrm{mm} / \mathrm{h})$ & (hh:mm:ss) & (years) \\
\hline 25 & 01/03/2016; 00:00 & 4.1 & $01: 21$ & 3.0 & 15.2 & $72: 37$ & $<1$ \\
\hline 26 & 01/03/2016; 07:19 & 31.0 & $15: 33$ & 2.0 & 45.7 & $05: 58$ & $<1$ \\
\hline 27 & $03 / 03 / 2016 ; 06: 13$ & 40.9 & $18: 14$ & 2.2 & 61.0 & $31: 21$ & $<1$ \\
\hline 28 & $07 / 03 / 2016 ; 06: 13$ & 7.4 & $14: 36$ & 0.5 & 15.2 & $77: 46$ & $<1$ \\
\hline 29 & $09 / 03 / 2016 ; 14: 42$ & 4.8 & $06: 51$ & 0.7 & 15.2 & $41: 52$ & $<1$ \\
\hline 30 & $12 / 03 / 2016 ; 06: 27$ & 6.1 & 08:03 & 0.8 & 15.2 & $56: 54$ & $<1$ \\
\hline 31 & $15 / 03 / 2016 ; 08: 06$ & 9.1 & 01:49 & 5.0 & 30.5 & $65: 36$ & $<1$ \\
\hline 32 & $16 / 03 / 2016 ; 14: 38$ & 27.9 & $20: 10$ & 1.4 & 30.5 & $29: 33$ & $<1$ \\
\hline 33 & $23 / 03 / 2016 ; 07: 43$ & 34.3 & $22: 30$ & 1.5 & 91.4 & $140: 55$ & $<1$ \\
\hline 34 & $24 / 03 / 2016 ; 23: 08$ & 2.8 & 01:15 & 2.2 & 15.2 & $16: 55$ & $<1$ \\
\hline 35 & $08 / 04 / 2016 ; 08: 33$ & 5.3 & $00: 54$ & 5.9 & 30.5 & $344: 10$ & $<1$ \\
\hline 36 & $08 / 04 / 2016 ; 21: 12$ & 2.3 & $02: 12$ & 1.0 & 15.2 & $11: 46$ & $<1$ \\
\hline 37 & $09 / 04 / 2016 ; 20: 39$ & 15.7 & $08: 36$ & 1.8 & 30.5 & $21: 13$ & $<1$ \\
\hline 38 & $23 / 04 / 2016 ; 18: 12$ & 8.1 & $00: 36$ & 13.5 & 61.0 & $325: 01$ & $<1$ \\
\hline 39 & $24 / 04 / 2016 ; 04: 00$ & 11.2 & $11: 12$ & 1.0 & 106.7 & 09:13 & $<1$ \\
\hline 40 & $25 / 04 / 2016 ; 04: 38$ & 2.5 & 02:00 & 1.3 & 15.2 & $13: 27$ & $<1$ \\
\hline 41 & $25 / 04 / 2016 ; 12: 45$ & 8.1 & $05: 36$ & 1.5 & 76.2 & 06:07 & $<1$ \\
\hline 42 & $28 / 04 / 2016 ; 21: 44$ & 14.7 & $08: 36$ & 1.7 & 15.2 & $75: 25$ & $<1$ \\
\hline 43 & $01 / 05 / 2016 ; 11: 00$ & 3.3 & $07: 50$ & 0.4 & 15.2 & $52: 40$ & $<1$ \\
\hline 44 & $02 / 05 / 2016 ; 06: 28$ & 23.9 & $24: 54$ & 1.0 & 15.2 & $11: 40$ & $<1$ \\
\hline 45 & 04/05/2016; 03:49 & 5.3 & 04:00 & 1.3 & 15.2 & $20: 25$ & $<1$ \\
\hline 46 & $12 / 05 / 2016 ; 03: 47$ & 3.6 & $09: 36$ & 0.4 & 30.5 & 188:01 & $<1$ \\
\hline 47 & $14 / 05 / 2016 ; 19: 09$ & 35.6 & $21: 42$ & 1.6 & 61.0 & $53: 48$ & $<1$ \\
\hline 48 & $20 / 05 / 2016 ; 09: 15$ & 2.5 & $02: 48$ & 0.9 & 15.2 & $112: 27$ & $<1$ \\
\hline 49 & $13 / 06 / 2016 ; 01: 01$ & 2.8 & 03:30 & 0.8 & 15.2 & $564: 57$ & $<1$ \\
\hline 50 & $19 / 06 / 2016 ; 11: 34$ & 2.5 & 06:00 & 0.4 & 15.2 & 151:06 & $<1$ \\
\hline 51 & $24 / 06 / 2016 ; 03: 34$ & 7.9 & $01: 42$ & 4.6 & 15.2 & $106: 03$ & $<1$ \\
\hline 52 & $26 / 07 / 2016 ; 14: 43$ & 2.0 & $00: 12$ & 10.2 & 45.7 & $777: 28$ & $<1$ \\
\hline 53 & $07 / 08 / 2016 ; 13: 28$ & 8.4 & $10: 24$ & 0.8 & 15.2 & $286: 34$ & $<1$ \\
\hline 54 & $11 / 08 / 2016 ; 22: 29$ & 2.3 & $00: 12$ & 11.5 & 30.5 & $391: 36$ & $<1$ \\
\hline 55 & $23 / 08 / 2016 ; 14: 51$ & 22.4 & $22: 06$ & 1.0 & 76.2 & $280: 10$ & $<1$ \\
\hline 56 & $31 / 08 / 2016 ; 23: 31$ & 6.9 & $06: 54$ & 1.0 & 30.5 & 178:37 & $<1$ \\
\hline 57 & $06 / 09 / 2016 ; 03: 44$ & 36.3 & $07: 12$ & 5.0 & 76.2 & $117: 21$ & $<1$ \\
\hline 58 & 08/09/2016; 03:50 & 13.7 & $07: 18$ & 1.9 & 15.2 & $40: 52: 48$ & $<1$ \\
\hline 59 & $13 / 09 / 2016 ; 15: 29$ & 12.5 & $02: 42$ & 4.6 & 91.4 & $124: 24$ & $<1$ \\
\hline 60 & $17 / 09 / 2016 ; 04: 22$ & 7.9 & $05: 48$ & 1.4 & 45.7 & $82: 10$ & $<1$ \\
\hline 61 & $18 / 09 / 2016 ; 23: 19$ & 38.9 & $20: 48$ & 1.9 & 61.0 & $37: 10$ & $<1$ \\
\hline \multirow[t]{5}{*}{62} & $22 / 09 / 2016 ; 05: 49$ & 2.3 & $00: 42$ & 3.3 & 15.2 & $57: 40$ & $<1$ \\
\hline & Mean & 20.3 & $11: 47$ & 2.5 & 40.8 & $129: 27$ & \\
\hline & Minimum & 2.0 & $00: 12$ & 0.4 & 15.2 & $05: 58$ & \\
\hline & Maximum & 120.1 & $61: 31$ & 13.5 & 167.6 & $777: 28$ & \\
\hline & Sum & 1256.3 & & & & & \\
\hline
\end{tabular}

October 2015, with $340.4 \mathrm{~mm}$ of precipitation depth ( $24.2 \%$ of the total considered period), was the wettest month, whereas July 2016, with only $2.0 \mathrm{~mm}$, was the driest month in this experimental period.

By comparing all the 62 monitored storms events in terms of total rainfall depth and duration with the relevant intensity-duration-frequency (IDF) curves, which considered the event return periods found using the historical data collected from the rain gauge station in Cosenza, it emerges that most of the rainfall events fall below the one-year return period threshold. This finding is important for the analysis of the precipitation events, and for the subsequent evaluations of the hydraulic efficiency of the green roof. 


\subsection{Green Roof Hydrologic Effectiveness}

To evaluate the hydrological performance of the experimental green roof, the runoff volume-which was generated in response to the 62 rainfall events recorded at the experimental site-and the hydrological indicators, were both analyzed.

Table 2 reports the results obtained in terms of total runoff depth (RD) and subsurface runoff coefficient (SRC) for each event. For peak flow reduction (PFR), peak flow lag-time (PFL), and time to start runoff (TSR), only the results for rainfall events with a precipitation depth (PD) greater than $8 \mathrm{~mm}$ are shown. In detail, the choice to evaluate the PFR, PFL, and TSR indexes for only for some events was based on the evaluations conducted on rainfall events with precipitation depths less than $8 \mathrm{~mm}$, which were almost completely preserved by the green roof. In this regard, having found a minimal runoff for these events, it was difficult to identify a demarcated hydrograph peak as well as the start of the hydrograph, which was considerably delayed. The same situation was found for event 53 , which, despite having a rainfall depth of $8.4 \mathrm{~mm}$, had a minimal runoff volume that was probably affected by the long event duration and the high temperature of the period (August), and therefore was not suitable for the analysis. Table 2 also reports the mean, minimum, and maximum values for each hydrological indicator.

Table 2. Hydrological performance indicators for GR at event scale. PD-precipitation depth, $R D$-runoff depth, $S R C$ — subsurface runoff coefficient, $P F R$ - peak flow reduction, $P F L$ —peak flow lag-time, TSR - time to start runoff.

\begin{tabular}{|c|c|c|c|c|c|c|c|}
\hline No. & Date & PD & RD & SRC & PFR & PFL & TSR \\
\hline & (dd/mm/yyyy; hh:mm) & $(\mathrm{mm})$ & $(\mathrm{mm})$ & $(\%)$ & $(\%)$ & $(\min )$ & $(\min )$ \\
\hline 1 & 07/10/2015; 07:47 & 42.2 & 20.0 & 47.4 & 65.4 & 6.0 & 17.0 \\
\hline 2 & 09/10/2015; 19:21 & 24.1 & 10.8 & 44.8 & 17.9 & 5.0 & 23.0 \\
\hline 3 & $10 / 10 / 2015 ; 23: 25$ & 48.3 & 31.0 & 64.2 & 13.3 & 2.0 & 10.0 \\
\hline 4 & $15 / 10 / 2015 ; 08: 01$ & 6.4 & 0.4 & 6.3 & - & - & - \\
\hline 5 & $21 / 10 / 2015 ; 14: 51$ & 120.1 & 100.0 & 83.3 & 28.3 & 9.0 & 30.0 \\
\hline 6 & $29 / 10 / 2015 ; 13: 10$ & 63.3 & 46.4 & 73.3 & 52.6 & 531.0 & 51.0 \\
\hline 7 & $21 / 11 / 2015 ; 23: 26$ & 37.1 & 13.0 & 35.0 & 83.0 & 468.0 & 200.0 \\
\hline 8 & $23 / 11 / 2015 ; 16: 30$ & 13.0 & 4.2 & 32.3 & 82.0 & 197.0 & 60.0 \\
\hline 9 & $24 / 11 / 2015 ; 17: 24$ & 97.3 & 79.5 & 81.7 & 44.3 & 207.0 & 10.0 \\
\hline 10 & $28 / 11 / 2015 ; 08: 49$ & 2.8 & 0.4 & 14.3 & - & - & - \\
\hline 11 & $10 / 12 / 2015 ; 13: 05$ & 8.4 & 1.6 & 19.0 & 95.2 & 168.0 & 15.0 \\
\hline 12 & 03/01/2016; 06:04 & 66.3 & 32.7 & 49.3 & 75.5 & 1647.0 & 54.0 \\
\hline 13 & $05 / 01 / 2016 ; 02: 51$ & 3.3 & 0.3 & 9.1 & - & - & - \\
\hline 14 & $06 / 01 / 2016 ; 05: 45$ & 24.6 & 12.9 & 52.4 & 51.3 & 57.0 & 5.0 \\
\hline 15 & 07/01/2016; 19:36 & 9.9 & 6.4 & 64.6 & 36.6 & 369.0 & 3.0 \\
\hline 16 & $12 / 01 / 2016 ; 19: 02$ & 6.1 & 1.1 & 18.0 & - & - & - \\
\hline 17 & $15 / 01 / 2016 ; 21: 39$ & 24.9 & 13.2 & 53.0 & 29.6 & 1447.0 & 24.0 \\
\hline 18 & 11/02/2016; 08:01 & 23.4 & 4.1 & 17.5 & 79.7 & 18.0 & 42.0 \\
\hline 19 & $12 / 02 / 2016 ; 06: 25$ & 18.8 & 11.1 & 59.0 & 27.6 & 58.0 & 102.0 \\
\hline 20 & $12 / 02 / 2016 ; 23: 22$ & 74.9 & 56.0 & 74.8 & 22.5 & 8.0 & 5.0 \\
\hline 21 & $18 / 02 / 2016 ; 05: 26$ & 45.2 & 30.4 & 67.3 & 33.6 & 55.0 & 39.0 \\
\hline 22 & $20 / 02 / 2016 ; 12: 15$ & 4.6 & 0.9 & 19.6 & - & - & - \\
\hline 23 & $23 / 02 / 2016 ; 22: 11$ & 3.1 & 0.1 & 3.2 & - & - & - \\
\hline 24 & $26 / 02 / 2016 ; 03: 52$ & 10.9 & 4.6 & 42.2 & 73.6 & 13.0 & 42.0 \\
\hline 25 & 01/03/2016; 00:00 & 4.1 & 0.7 & 17.1 & - & - & - \\
\hline 26 & 01/03/2016; 07:19 & 31.0 & 19.9 & 64.2 & 32.1 & 49.0 & 73.0 \\
\hline 27 & $03 / 03 / 2016 ; 06: 13$ & 40.9 & 29.4 & 71.9 & 41.3 & 1280.0 & 154.0 \\
\hline 28 & $07 / 03 / 2016 ; 06: 13$ & 7.4 & 2.1 & 28.4 & - & - & - \\
\hline 29 & 09/03/2016; 14:42 & 4.8 & 0.9 & 18.8 & - & - & - \\
\hline 30 & $12 / 03 / 2016 ; 06: 27$ & 6.1 & 1.6 & 26.2 & - & - & - \\
\hline 31 & $15 / 03 / 2016 ; 08: 06$ & 9.1 & 3.8 & 41.8 & 44.9 & 124.0 & 3.0 \\
\hline
\end{tabular}


Table 2. Cont.

\begin{tabular}{|c|c|c|c|c|c|c|c|}
\hline No. & Date & PD & RD & SRC & PFR & PFL & TSR \\
\hline & (dd/mm/yyyy; hh:mm) & $(\mathrm{mm})$ & $(\mathrm{mm})$ & $(\%)$ & $(\%)$ & (min) & $(\min )$ \\
\hline 32 & $16 / 03 / 2016 ; 14: 38$ & 27.9 & 19.4 & 69.5 & 41.6 & 897.0 & 73.0 \\
\hline 33 & $23 / 03 / 2016 ; 07: 43$ & 34.3 & 16.1 & 46.9 & 74.5 & 9.0 & 26.0 \\
\hline 34 & $24 / 03 / 2016 ; 23: 08$ & 2.8 & 0.1 & 3.6 & - & - & - \\
\hline 35 & 08/04/2016; 08:33 & 5.3 & 0.3 & 5.7 & - & - & - \\
\hline 36 & $08 / 04 / 2016 ; 21: 12$ & 2.3 & 0.0 & 0.0 & - & - & - \\
\hline 37 & $09 / 04 / 2016 ; 20: 39$ & 15.7 & 5.8 & 36.9 & 86.5 & 8.0 & 11.0 \\
\hline 38 & $23 / 04 / 2016 ; 18: 12$ & 8.1 & 1.8 & 22.2 & 92.9 & 11.0 & 15.0 \\
\hline 39 & $24 / 04 / 2016 ; 04: 00$ & 11.2 & 2.9 & 25.9 & 62.1 & 4.0 & 10.0 \\
\hline 40 & $25 / 04 / 2016 ; 04: 38$ & 2.5 & 0.2 & 8.0 & - & - & - \\
\hline 41 & $25 / 04 / 2016 ; 12: 45$ & 8.1 & 4.2 & 51.9 & 73.3 & 1.0 & 4.0 \\
\hline 42 & $28 / 04 / 2016 ; 21: 44$ & 14.7 & 5.8 & 39.5 & $*$ & 521.0 & 108.0 \\
\hline 43 & $01 / 05 / 2016 ; 11: 00$ & 3.3 & 0.3 & 9.1 & - & - & - \\
\hline 44 & $02 / 05 / 2016 ; 06: 28$ & 23.9 & 16.9 & 70.7 & 72.8 & 1253.0 & 399.0 \\
\hline 45 & $04 / 05 / 2016 ; 03: 49$ & 5.3 & 1.3 & 24.5 & - & - & - \\
\hline 46 & $12 / 05 / 2016 ; 03: 47$ & 3.6 & 0.0 & 0.0 & - & - & - \\
\hline 47 & $14 / 05 / 2016 ; 19: 09$ & 35.6 & 23.3 & 65.4 & 38.3 & 512.0 & 132.0 \\
\hline 48 & 20/05/2016; 09:15 & 2.5 & 0.0 & 0.0 & - & - & - \\
\hline 49 & $13 / 06 / 2016 ; 01: 01$ & 2.8 & 0.0 & 0.0 & - & - & - \\
\hline 50 & $19 / 06 / 2016 ; 11: 34$ & 2.5 & 0.0 & 0.0 & - & - & - \\
\hline 51 & $24 / 06 / 2016 ; 03: 34$ & 7.9 & 0.2 & 2.5 & - & - & - \\
\hline 52 & $26 / 07 / 2016 ; 14: 43$ & 2.0 & 0.0 & 0.0 & - & - & - \\
\hline 53 & $07 / 08 / 2016 ; 13: 28$ & 8.4 & 0.2 & 2.4 & - & - & - \\
\hline 54 & $11 / 08 / 2016 ; 22: 29$ & 2.3 & 0.0 & 0.0 & - & - & - \\
\hline 55 & $23 / 08 / 2016 ; 14: 51$ & 22.4 & 7.2 & 32.1 & 93.0 & 5.0 & 1.0 \\
\hline 56 & $31 / 08 / 2016 ; 23: 31$ & 6.9 & 0.0 & 0.0 & - & - & - \\
\hline 57 & 06/09/2016; 03:44 & 36.3 & 13.4 & 36.9 & * & 34.0 & 28.0 \\
\hline 58 & 08/09/2016; 03:50 & 13.7 & 5.1 & 37.2 & 74.2 & 324.0 & 5.0 \\
\hline 59 & $13 / 09 / 2016 ; 15: 29$ & 12.5 & 4.4 & 35.2 & 89.5 & 8.0 & 3.0 \\
\hline 60 & $17 / 09 / 2016 ; 04: 22$ & 7.9 & 0.4 & 5.1 & - & - & - \\
\hline 61 & $18 / 09 / 2016 ; 23: 19$ & 38.9 & 20.9 & 53.7 & 19.0 & 16.0 & 45.0 \\
\hline \multirow[t]{9}{*}{62} & $22 / 09 / 2016 ; 05: 49$ & 2.3 & 0.0 & 0.0 & - & - & - \\
\hline & Mean $(* *)$ & 20.3 & 11.1 & 32.0 & & & \\
\hline & $\operatorname{Minimum}(* *)$ & 2.0 & 0.0 & 0.0 & & & \\
\hline & Maximum (**) & 120.1 & 100.00 & 83.3 & & & \\
\hline & $\operatorname{Sum}(* *)$ & 1256.3 & 689.7 & & & & \\
\hline & Mean $(* * *)$ & 32.5 & 19.4 & 50.4 & 56.0 & 294.9 & 52.1 \\
\hline & Minimum $(* * *)$ & 8.1 & 1.6 & 17.5 & 13.3 & 1 & 1 \\
\hline & Maximum (***) & 120.1 & 100 & 83.3 & 95.2 & 1647 & 399 \\
\hline & $\operatorname{Sum}(* * *)$ & 1137.0 & 678.2 & & & & \\
\hline
\end{tabular}

* Due to an interruption of the sensor signal, it was not possible to evaluate the runoff from the conventional roof (IR); thus, the result in terms of PFR was not evaluated; ** Values evaluated considering the whole dataset (62 rainfall events); ${ }^{* * *}$ Values estimated by excluding the storm events with rainfall depth less than $8 \mathrm{~mm}$ and the rainfall event 53 .

By analyzing the results in Table 2, we found that the SRC exhibits a high variability, ranging from $0 \%$ to $83.3 \%$ with a mean value of $32.0 \%$ when the whole dataset ( 62 storms event) was considered; meanwhile, it ranges from $17.5 \%$ to $83.3 \%$ with a mean value of $50.4 \%$ for storm events with rainfall depths more than $8 \mathrm{~mm}$ ( 26 events) and excluding event 53 , too. In this regard, this increase of the mean value of SRC is due to the exclusion by the average evaluation of 27 storm events, which were almost totally retained by the green roof, and are the same events that are not considered also for the other indexes (PFR, PFL and TSR). This first result, in accordance with a previous study carried out for an extensive green roof in Mediterranean climate [23] and fully falling within the range of the variation mentioned in Section 1 (30-90\%), confirms the good response of the specific GR, but simultaneously 
highlights how the SRC index is strongly influenced by weather conditions. For example, by comparing two events with different rainfall depths, such as Event $9(\mathrm{PD}=97.3 \mathrm{~mm})$ and Event $18(\mathrm{PD}=23.4$ $\mathrm{mm})$, the SRC values were $81.7 \%$ and $17.5 \%$, respectively. Two events with similar rainfall depths, such as Event $7(\mathrm{PD}=37.1 \mathrm{~mm})$ and Event $27(\mathrm{PD}=40.9 \mathrm{~mm})$, produced $\mathrm{SRC}$ values of $35.0 \%$ and $71.9 \%$, respectively. These differences in SRC given similar precipitation can be understood by observing the antecedent dry weather period (ADWP) of the two events, which affects the initial soil moisture condition and therefore the soil retention capacity. Event 7, with a retention of $65.0 \%$ (SRC $=35.0 \%)$, occurred after more than 20 continuous dry days, whereas when Event 27 happened, at the beginning of the event, the soil substrate had a reduced retention capacity due to the short ADWP (just over one day); therefore, this results in a higher SRC than Event 7.

A similar conclusion can be reached by observing the other three indices (PFR, PFL, and TSR) in Table 2. We found that PFR, PFL, and TSR — with mean values of 56.0\%, $294.9 \mathrm{~min}$, and $52.1 \mathrm{~min}$, respectively-were highly variable, and principally associated with the climate condition before the beginning of the storm events, and therefore, with the initial humidity of the soil.

By considering the results in Figure 2, which shows the regression plots (significance level equal of 0.5) estimated for selected hydrological parameters, we noted a linear strong relationship $\left(R^{2}=\right.$ $0.95)$ between RD and PD (Figure 2a) and a logarithmic relationship $\left(R^{2}=0.77\right)$ between SRC and PD (Figure $2 b$ ). By analyzing the Figure 2a, we found that RD tended to be 0 to $10 \mathrm{~mm}$ for PD values lower than $20 \mathrm{~mm}$, whereas Figure $2 \mathrm{~b}$ shows SRC values ranging between $\sim 75-85 \%$ for PD greater than 70 $\mathrm{mm}$, and a significant variation in the SRC value for PD less than $10 \mathrm{~mm}$, principally depending on the ADWP.
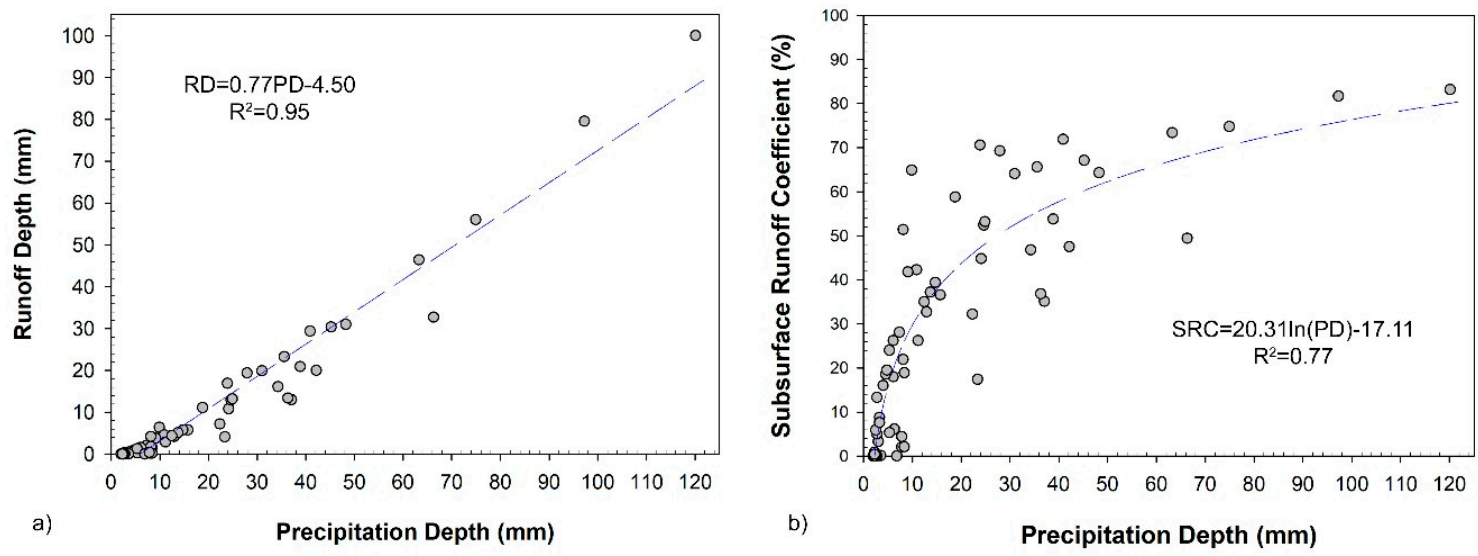

Figure 2. Regression plots (significance level $=0.05$ ) for selected key parameters, by using all the rainfall events: (a) runoff depth (RD) as a function of precipitation depth (PD) and (b) subsurface runoff coefficient (SRC) as a function of precipitation depth (PD).

All these findings confirm the findings reported in the literature [3,11], which identified ADWP as a significant determinant of hydrological performance. This specific hydrological parameter, which ranged from around 6 hours to more than 777 hours in this study (Table 1), significantly affects the substrate moisture conditions and thus the green roof hydrological response in terms of SRC, PFR, PFL, and TSR indexes.

All the results that were analytically evaluated in terms of runoff volume, rainfall intensity, and hydrological indexes, provided excellent feedback, as shown in Figure 3, where hyetographs and corresponding hydrographs of the GR (black line) and the IR (grey color) are shown for eight selected rainfall events. These storms events were selected to cover a wide range of precipitation depths, durations, and antecedent dry weather conditions. The events shown in Figure 3 confirm the hydrological efficiency of the experimental green roof in terms of runoff volume reduction and peak hydrograph mitigation compared to the conventional roof, and the delay in peak flow compared with the hyetograph. 

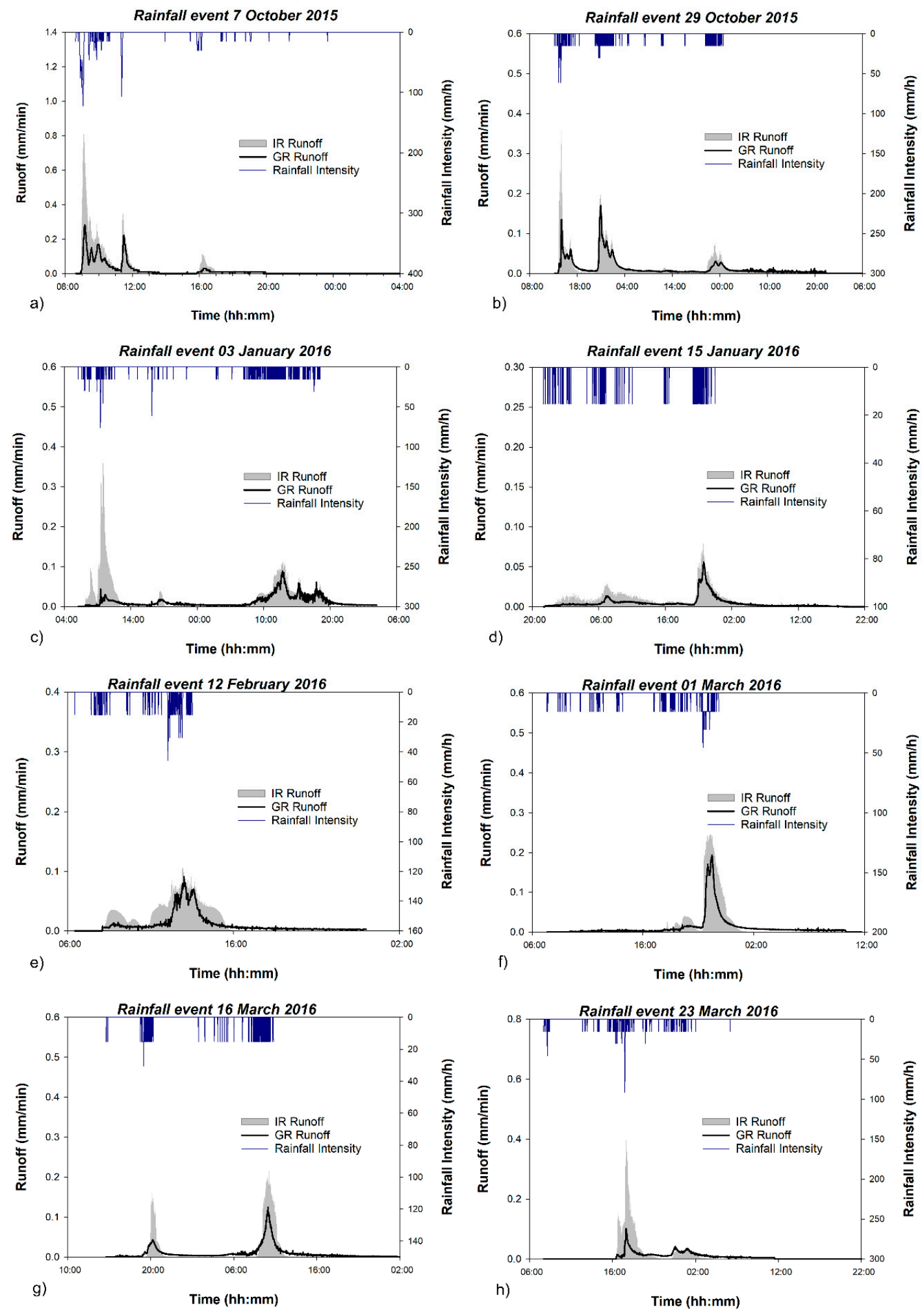

Figure 3. Hyetographs and corresponding green roof (GR) and impervious roof (IR) runoff hydrographs for eight selected rainfall events: (a) 7 October 2015 (total precipitation depth (PD) $=42.2 \mathrm{~mm}$ and total green roof runoff depth $(\mathrm{GR}-\mathrm{RD})=20.0 \mathrm{~mm})$; (b) 29 October $2015(\mathrm{PD}=63.3 \mathrm{~mm}$ and GR-RD $=46.4 \mathrm{~mm})$; (c) 03 January $2016(\mathrm{PD}=66.3 \mathrm{~mm}$ and GR-RD = $32.7 \mathrm{~mm})$; (d) 15 January $2016(\mathrm{PD}=24.9 \mathrm{~mm}$ and GR-RD = $13.2 \mathrm{~mm}$ ); (e) 12 February 2016 (PD = $18.8 \mathrm{~mm}$ and GR-RD = $11.1 \mathrm{~mm})$; (f) 01 March 2016 $(\mathrm{PD}=31.0 \mathrm{~mm}$ and GR-RD = $19.9 \mathrm{~mm}) ;(\mathrm{g}) 16 \mathrm{March} 2016(\mathrm{PD}=27.9 \mathrm{~mm}$ and GR-RD = $19.4 \mathrm{~mm})$; (h) 23 March 2016 (PD = $34.3 \mathrm{~mm}$ and GR-RD = $16.1 \mathrm{~mm}$ ). 


\subsection{Soil Hydraulic Properties}

The soil hydraulic properties of the soil substrate measured with the evaporation method are shown in Figure 4. The measured soil water retention curve (SWRC) is well described across the entire water content range (blue points of the left-side curve), whereas the measured points of the hydraulic conductivity function (blue points of the central and right-side curve) are concentrated in the dry range between $10-30 \%$ of the volumetric water content. The measured data were imported into HYPROP-FIT (METER Group AG, Munich, Germany) software to fit the analytical hydraulic property functions.
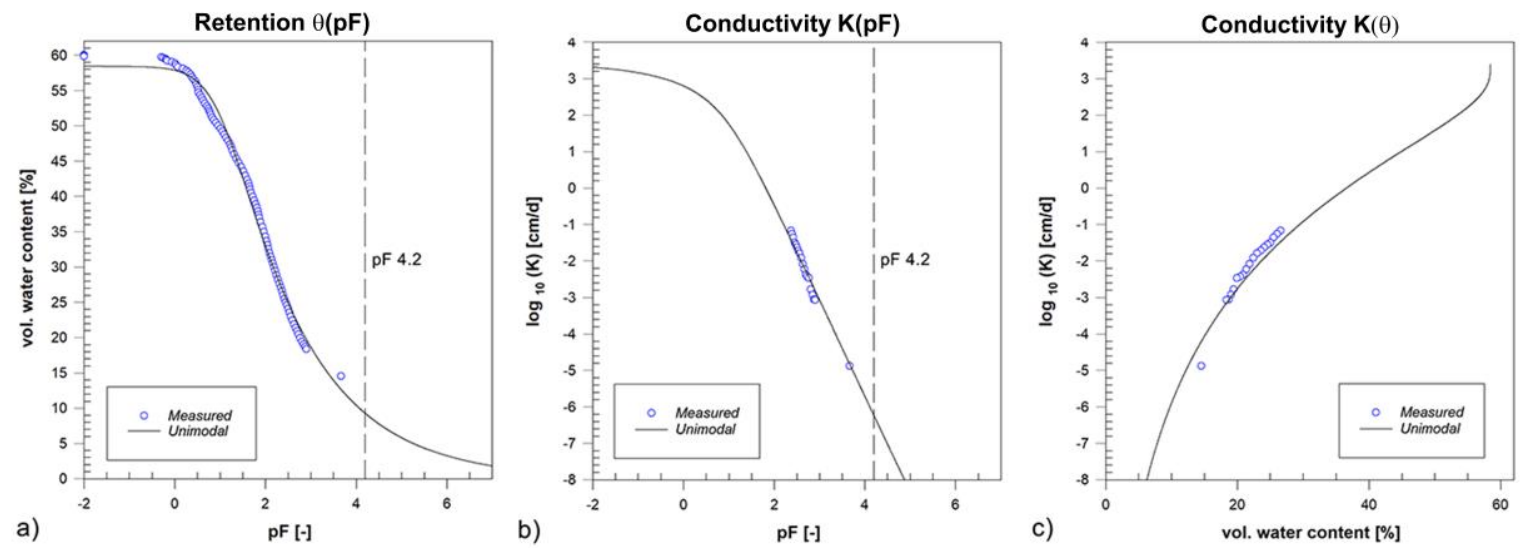

Figure 4. (a) The soil water retention curve showing the volumetric water content $(\theta)$ versus $\mathrm{pF}$ (decimal $\log$ of tension, expressed as pressure head in the unit of $\mathrm{cm}$ ); (b) the conductivity curves showing the $\log$ of the hydraulic conductivity $(\mathrm{K})$ versus $\mathrm{pF}$, and (c) the log of hydraulic conductivity versus volumetric water content $(\theta)$.

The unimodal van Genuchten Mualem model (VGM) [49] was fitted (Figure 4, black line). The root mean square error (RMSE) values for retention and conductivity functions were $0.01 \mathrm{~cm}^{3} \mathrm{~cm}^{-3}$ and $0.16 \log \mathrm{K}, \mathrm{cm} /$ day, respectively.

The hydraulic properties obtained by fitting the van Genuchten Mualem model and their limit of confidence are described in Table 3, where $\alpha$ is a parameter related to the inverse of the air-entry pressure head $\left(\mathrm{L}^{-1}\right) ; \theta_{s}$ and $\theta_{r}$ are the saturated and residual water contents, respectively; $n$ is a pore-size distribution index; $K_{s}$ is the saturated hydraulic conductivity $\left(\mathrm{LT}^{-1}\right)$; and $l$ is the tortuosity and pore-connectivity parameter.

Table 3. Estimated soil hydraulic parameters. $\theta_{r}$, residual water content; $\theta_{s}$, saturated water content; $\alpha$, inverse of the air-entry pressure head; $n$, pore-size distribution index; and $l$, tortuosity.

\begin{tabular}{ccccc}
\hline Parameter & Value & Lower Limit & Upper Limit & Unit of Measure \\
\hline$\theta_{r}$ & 0.00 & 0 & 0.07 & $\mathrm{~cm}^{3} \mathrm{~cm}^{-3}$ \\
$\theta_{s}$ & 0.58 & 0.57 & 0.59 & $\mathrm{~cm}^{3} \mathrm{~cm}^{-3}$ \\
$\alpha$ & 0.09 & 0.07 & 0.11 & $\mathrm{~cm}^{-1}$ \\
$n$ & 1.25 & 1.20 & 1.32 & - \\
$K_{s}$ & 3000 & 0.00 & 4000 & $\mathrm{~cm} \mathrm{day}^{-1}$ \\
$l$ & 0.5 & - & - & - \\
\hline
\end{tabular}

The model used indicates a soil characterized by a very high permeability, which corresponds well with the textural composition of the GR substrate. This characteristic is well suited for green roof substrates, which must guarantee fast drainage and avoid water ponding on the surface, even during intense precipitation. Narrow confidence intervals for parameters indicate high confidence in their estimation, whereas a huge range in the estimation of $K_{s}$ indicates that the evaporation method is not accurate for the determination of the hydraulic conductivity near saturation, and this is reflected in 
the estimation of $K_{s}$. To improve the accuracy in the estimation of the hydraulic conductivity near saturation, other methods and devices should be used such as Ksat [52] based on the Darcy experiment.

\subsection{Green Roof Hydraulic Behavior for Different Soil Depths}

As stated above, the hydraulic parameters of the soil substrate were used in HYDRUS-1D to describe the hydrological behavior of the green roof with different soil depths.

Cumulative inflow and outflow fluxes of the green roof are reported in Figure 5. By increasing the soil substrate depth, the green roof was able to reduce the total runoff volume from $22 \%$ to $24 \%$ in response to the same total precipitation during the considered period.

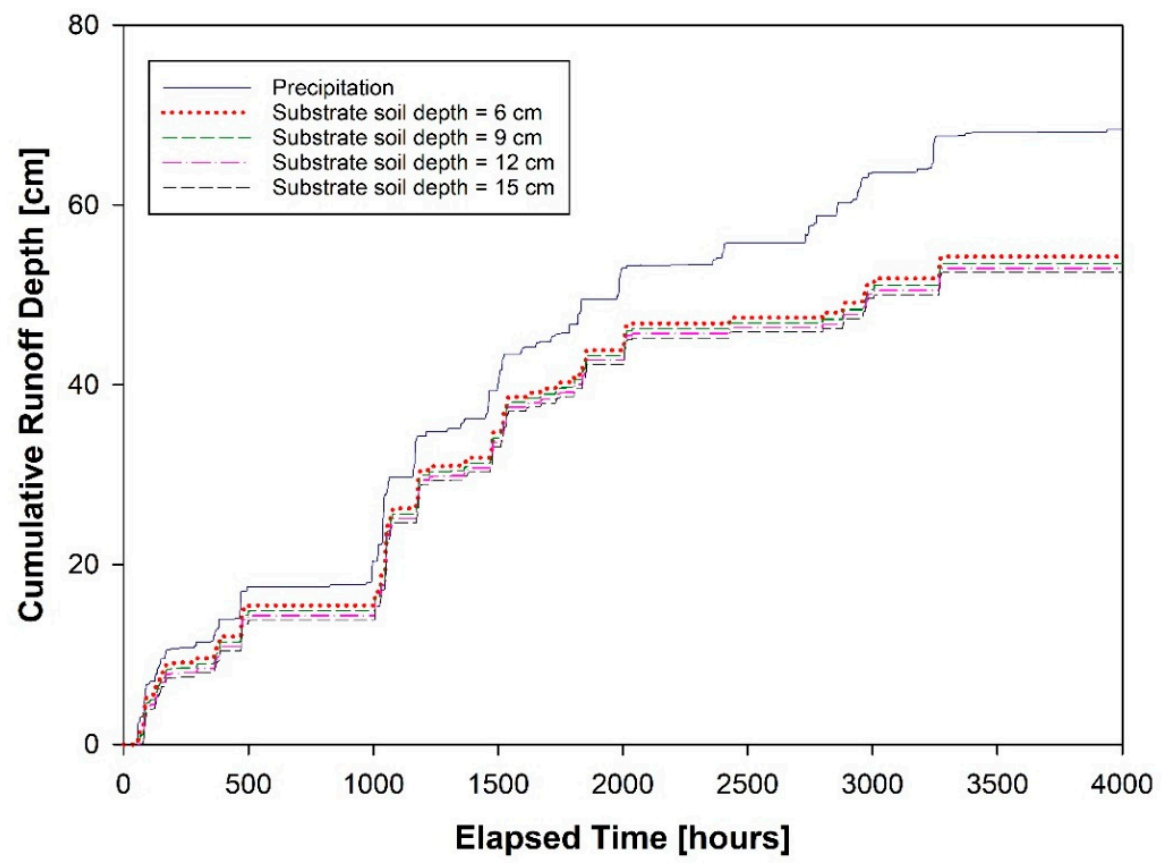

Figure 5. Cumulative rainfall and cumulative modeled runoff for different values of soil depth $(\mathrm{H})$ by considering a six-month dataset (January-June 2016).

The steep gradients in the cumulative outflow indicate that the green roof responded quickly to precipitation. This aspect is directly related to the limited thickness of the substrate, which reduces the possible delay.

During simulations, mass balance errors were always below $1 \%$, which is generally considered acceptable at these low levels.

As shown in Figure 5, the outflow volume reduction achieved by doubling the soil substrate depth under the same climate conditions was not significant. This result, which confirms the findings of Feitosa and Wilkinson [32], can be justified by observing that the six-month dataset used for these simulations was obtained in winter and spring, where evapotranspiration is not predominant. Based on these findings, since the adoption of a deeper soil depth does not contribute to a significant increase in the retention capacity, it would only represent a structural overloading, while a substrate depth of six centimeters would be an ideal soil depth for extensive green roofs.

\section{Conclusions}

Green roofs may be a solution for minimizing the impact of urbanization on the hydrologic cycle. Given the important role they play in the mitigation of urban flooding, several studies have focused on the analysis of their hydraulic behavior.

In this study, we conducted a field monitoring campaign for one year on a full-scale extensive green roof. We evaluated hydrological indices (subsurface runoff coefficient, peak flow reduction, peak 
flow lag-time, and time to start runoff) on an event scale, and we found possible correlations between these indicators and hydrological features of storm events. The findings showed that the subsurface runoff coefficient (SRC) ranges from $17.5 \%$ to $83.3 \%$ with an average value of $50.4 \%$ for the rainfall events with a precipitation depth more than $8 \mathrm{~mm}$ ( 35 rainfall events) and by excluding Event 53 , which presents an average value of $32.0 \%$ for the whole dataset (62 rainfall events). This result, which is evaluated by considering an event scale analysis, falls in the range (around 30-90\%) evaluated in literature [30] under different climate conditions and temporally scales. In addition, as the subsurface runoff coefficient is an extremely useful index to quantify the hydraulic efficiency of a green roof, this finding confirms the optimal retention capacity of the experimental green roof in the Mediterranean climate. Therefore, the average value of the subsurface runoff that was obtained in this study for the specific green roof can be taken into account during preliminary design choices for the construction of green roofs in Mediterranean climate conditions.

Finally, to evaluate the influence of soil thickness on the hydraulic behavior of a green roof, the HYDRUS 1D model was used to consider green roofs with soil depths of $6 \mathrm{~cm}, 9 \mathrm{~cm}, 12 \mathrm{~cm}$, and $15 \mathrm{~cm}$. The results obtained in this phase show how the considered substrate depths for green roofs were able to achieve a runoff volume reduction of $22 \%$ to $24 \%$ during the selected period for the Mediterranean climate conditions without observing flow over the top surface of the soil. These findings are in accordance with the literature [32], which may be explained by the dataset used in these simulations being obtained during winter and spring where evapotranspiration, one of the key factors reducing storm water in the hydrological cycle, was not predominant. Thus, in the field of extensive green roofs, as the outflow volume reduction achieved by increasing the soil depth was not significant, the ideal depth for soil substrate would be six centimeters.

Finally, since the outflow volume reduction achieved by doubling the soil substrate depth under the same climate conditions is not significant, the maximum depth of $15 \mathrm{~cm}$ is not recommended for adoption considering the structural overloading.

Author Contributions: The authors contributions in the realization of the paper have been as follows. Conceptualization, S.A.P., M.T., F.P, and P.P.; methodology, S.A.P. and M.T.; data curation, S.A.P., M.T., and F.P.; formal analysis, S.A.P. and M.T.; investigation, S.A.P. and M.T.; writing—original draft preparation, S.A.P., M.T. and F.P.; writing—review, S.A.P. and M.T.; editing, S.A.P., M.T, and F.P.; supervision: P.P.

Funding: The study was co-funded by the Italian National Operative Project (PON) PON01_02543 “Integrated and sustainable management service for the water-energy cycle in urban drainage systems", Research and Competitiveness for the convergence regions 2007/2013, I Axis "Support to structural changes" operative objective 4.1.1.1. "Scientific-technological generators of transformation processes of the productive system and creation of new sectors" Action II: "Interventions to support industrial research".

Acknowledgments: We acknowledge the support by the Italian National Operative Project (PON) PON01_02543 "Integrated and sustainable management service for the water-energy cycle in urban drainage systems", Research and Competitiveness for the convergence regions 2007/2013, I Axis "Support to structural changes" operative objective 4.1.1.1. "Scientific-technological generators of transformation processes of the productive system and creation of new sectors" Action II: "Interventions to support industrial research".

Conflicts of Interest: The authors declare no conflict of interest.

\section{References}

1. Starzec, M.; Dziopak, J.; Słyś, D.; Pochwat, K.; Kordana, S. Dimensioning of Required Volumes of Interconnected Detention Tanks Taking into Account the Direction and Speed of Rain Movement. Water 2018, 10, 1826. [CrossRef]

2. Kordana, S. The identification of key factors determining the sustainability of stormwater systems. E3S Web Conf. 2018, 45, 00033. [CrossRef]

3. Piro, P.; Turco, M.; Palermo, S.A.; Principato, F.; Brunetti, G. A Comprehensive Approach to Stormwater Management Problems in the Next Generation Drainage Networks. In The Internet of Things for Smart Urban Ecosystems. Internet of Things (Technology, Communications and Computing); Cicirelli, F., Guerrieri, A., Mastroianni, C., Spezzano, G., Vinci, A., Eds.; Springer: Cham, Switzerland, 2019. [CrossRef] 
4. Pumo, D.; Arnone, E.; Francipane, A.; Caracciolo, D.; Noto, L.V. Potential implications of climate 363 change and urbanization on watershed hydrology. J. Hydrol. 2017, 554, 80-99. [CrossRef]

5. Palermo, S.A.; Zischg, J.; Sitzenfrei, R.; Rauch, W.; Piro, P. Parameter Sensitivity of a Microscale Hydrodynamic Model. In New Trends in Urban Drainage Modelling. UDM 2018; Green Energy and Technology; Mannina, G., Ed.; Springer: Cham, Switzerland, 2019; pp. 982-987.

6. Bhaskar, A.S.; Hogan, D.M.; Archfield, S.A. Urban base flow with low impact development. Hydrol. Process. 2016, 30, 3156-3171. [CrossRef]

7. Brunetti, G.; Šimůnek, J.; Turco, M.; Piro, P. On the use of global sensitivity analysis for the numerical analysis of permeable pavements. Urban Water J. 2018, 15, 269-275. [CrossRef]

8. Turco, M.; Brunetti, G.; Carbone, M.; Piro, P. Modelling the hydraulic behaviour of permeable pavements through a reservoir element model. Int. Multidiscip. Sci. GeoConf. SGEM 2018, 18, 507-514. [CrossRef]

9. Wang, X.; Tian, Y.; Zhao, X. The influence of dual-substrate-layer extensive green roofs on rainwater runoff quantity and quality. Sci. Total Environ. 2017, 592, 465-476. [CrossRef] [PubMed]

10. Voyde, E.; Fassman, E.; Simcock, R. Hydrology of an extensive living roof under sub-tropical climate conditions in Auckland, New Zealand. J. Hydrol. 2010, 394, 384-395. [CrossRef]

11. Stovin, V.; Vesuviano, G.; Kasmin, H. The hydrological performance of a green roof test bed under UK climatic conditions. J. Hydrol. 2012, 414, 148-161. [CrossRef]

12. Vijayaraghavan, K. Green roofs: A critical review on the role of components, benefits, limitations and trends. Renew. Sustain. Energy Rev. 2016, 57, 740-752. [CrossRef]

13. Pęczkowski, G.; Kowalczyk, T.; Szawernoga, K.; Orzepowski, W.; Żmuda, R.; Pokładek, R. Hydrological Performance and Runoff Water Quality of Experimental Green Roofs. Water 2018, 10, 1185. [CrossRef]

14. Bevilacqua, P.; Mazzeo, D.; Arcuri, N. Thermal inertia assessment of an experimental extensive green roof in summer conditions. Build. Environ. 2018, 131, 264-276. [CrossRef]

15. Santamouris, M. Cooling the cities-a review of reflective and green roof mitigation technologies to fight heat island and improve comfort in urban environments. Solar Energy 2014, 103, 682-703. [CrossRef]

16. Rowe, D.B. Green roofs as a means of pollution abatement. Environ. Pollut. 2011, 159, 2100-2110. [CrossRef] [PubMed]

17. Yang, H.S.; Kang, J.; Choi, M.S. Acoustic effects of green roof systems on a low-profiled structure at street level. Build. Environ. 2012, 50, 44-55. [CrossRef]

18. Buccola, N.; Spolek, G. A pilot-scale evaluation of green roof runoff retention, detention, and quality. Water Air Soil Pollut. 2011, 216, 83-92. [CrossRef]

19. Krebs, G.; Kuoppamäki, K.; Kokkonen, T.; Koivusalo, H. Simulation of green roof test bed runoff. Hydrol. Process. 2016, 30, 250-262. [CrossRef]

20. Carson, T.B.; Marasco, D.E.; Culligan, P.J.; McGillis, W.R. Hydrological performance of extensive green roofs in New York City: Observations and multi-year modeling of three full-scale systems. Environ. Res. Lett. 2013, 8, 024036. [CrossRef]

21. Fassman-Beck, E.; Voyde, E.; Simcock, R.; Hong, Y.S. 4 Living roofs in 3 locations: Does configuration affect runoff mitigation? J. Hydrol. 2013, 490, 11-20. [CrossRef]

22. Peng, Z.; Stovin, V. Independent validation of the SWMM green roof module. J. Hydrol. Eng. 2017, 22, 04017037. [CrossRef]

23. Cipolla, S.S.; Maglionico, M.; Stojkov, I. A long-term hydrological modelling of an extensive green roof by means of SWMM. Ecol. Eng. 2016, 95, 876-887. [CrossRef]

24. Principato, F.; Ferrante, A.P.; Frega, F.; Bartolo, M.; Piro, P. Mitigation of Urban Surface Runoff through LID Solutions: Case Study in Mediterranean Area. In New Trends in Urban Drainage Modelling. UDM 2018; Green Energy and Technology; Mannina, G., Ed.; Springer: Cham, Switzerland, 2019; pp. 665-670.

25. Metselaar, K. Water retention and evapotranspiration of green roofs and possible natural vegetation types. Resour. Conserv. Recycl. 2012, 64, 49-55. [CrossRef]

26. Palla, A.; Gnecco, I.; Lanza, L.G. Compared performance of a conceptual and a mechanistic hydrologic models of a green roof. Hydrol. Process. 2012, 26, 73. [CrossRef]

27. Brunetti, G.; Šimůnek, J.; Piro, P. A Comprehensive Analysis of the Variably Saturated 461 Hydraulic Behavior of a Green Roof in a Mediterranean Climate. Vadose Zone J. 2016, 15. [CrossRef]

28. Hilten, R.N.; Lawrence, T.M.; Tollner, E.W. Modeling stormwater runoff from green roofs with HYDRUS-1D. J. Hydrol. 2008, 358, 288-293. [CrossRef] 
29. Li, Y.; Babcock, R.W., Jr. Modeling hydrologic performance of a green roof system with HYDRUS-2D. J. Environ. Eng. 2015, 141, 04015036. [CrossRef]

30. Garofalo, G.; Palermo, S.; Principato, F.; Theodosiou, T.; Piro, P. The influence of hydrologic parameters on the hydraulic efficiency of an extensive green roof in mediterranean area. Water 2016, 8, 44. [CrossRef]

31. Liu, R.; Fassman-Beck, E. Hydrologic response of engineered media in living roofs and bioretention to large rainfalls: Experiments and modeling. Hydrol. Process. 2017, 31, 556-572. [CrossRef]

32. Feitosa, R.C.; Wilkinson, S. Modelling green roof stormwater response for different soil depths. Landsc. Urban Plan. 2016, 153, 170-179. [CrossRef]

33. Soulis, K.X.; Ntoulas, N.; Nektarios, P.A.; Kargas, G. Runoff reduction from extensive green roofs having different substrate depth and plant cover. Ecol. Eng. 2017, 102, 80-89. [CrossRef]

34. Piro, P.; Carbone, M.; Morimanno, F.; Palermo, S.A. Simple flowmeter device for LID systems: From laboratory procedure to full-scale implementation. Flow Meas. Instrum. 2019, 65, 240-249. [CrossRef]

35. Getter, K.L.; Rowe, D.B.; Andresen, J.A. Quantifying the effect of slope on extensive green roof stormwater retention. Ecol. Eng. 2007, 31, 225-231. [CrossRef]

36. Shiau, J.T. Return period of bivariate distributed extreme hydrological events. Stoch. Environ. Res. Risk Assess. 2003, 17, 42-57. [CrossRef]

37. Arpacal. 2019. Available online: http://www.cfd.calabria.it/index.php/dati-stazioni/dati-storici (accessed on 24 January 2019).

38. Allen, R.G.; Pereira, L.S.; Raes, D.; Smith, M. FAO Irrigation and Drainage Paper No. 56: Crop Evapotranspiration; FAO: Rome, Italy, 1998.

39. Lazzarin, R.M.; Castellotti, F.; Busato, F. Experimental measurements and numerical modelling of a green roof. Energy Build. 2005, 37, 1260-1267. [CrossRef]

40. Arya, L.M. Wind and hot-air methods. In Methods of Soil Analysis; Part 4. Physical Methods; Dane, J.H., Topp, G.C., Eds.; SSSA: Madison, WI, USA, 2002; pp. 916-926.

41. Dane, J.H.; Hopmans, J.W. Pressure plate extractor. In Methods of Soil Analysis; Part 4. Physical Methods; Dane, J.H., Topp, G.C., Eds.; SSSA: Madison, WI, USA, 2002; pp. 688-690.

42. Schindler, U. Ein Schnellverfahren zur Messung der Wasserleitfähigkeit im teilgesättigten Boden an Stechzylinderproben. Arch. Für Acker-Und Pflanzenbau Und Bodenkd. 1980, 24, 1-7.

43. Wind, G.P. Capillary conductivity data estimated by a simple method. Available online: https://library.wur. nl/WebQuery/wurpubs/fulltext/350954 (accessed on 3 July 2019).

44. Peters, A.; Durner, W. Simplified evaporation method for determining soil hydraulic properties. J. Hydrol. 2008, 356, 147-162. [CrossRef]

45. Schindler, U.; Durner, W.; von Unold, G.; Mueller, L.; Wieland, R. The evaporation method: Extending the measurement range of soil hydraulic properties using the air-entry pressure of the ceramic cup. J. Plant Nutr. Soil Sci. 2010, 173, 563-572. [CrossRef]

46. Schindler, U.; Durner, W.; von Unold, G.; Muller, L. Evaporation Method for Measuring Unsaturated Hydraulic Properties of Soils: Extending the Measurement Range. Soil Sci. Soc. Am. J. 2010, 74, 1071-1083. [CrossRef]

47. UMS GmbH. UMS (2015): Manual HYPROP, Version 2015-01; UMS GmbH: München, Germany, 8137; Volume 37.

48. Pertassek, T.; Peters, A.; Durner, W. HYPROP-FIT Software User's Manual, V.3.0; UMS GmbH: München, Germany, 2015.

49. Van Genuchten, M.T. A closed-form equation for predicting the hydraulic conductivity of unsaturated soils 1. Soil Sci. Soc. Am. J. 1980, 44, 892-898. [CrossRef]

50. Šimůnek, J.; van Genuchten, M.T.; Šejna, M. Recent Developments and Applications of the HYDRUS Computer Software Packages. Vadose Zone J. 2016, 15. [CrossRef]

51. Feddes, R.A.; Kowalik, P.J.; Zaradny, H. Simulation of Field Water Use and Crop Yield; PUDOC: Wageningen, The Netherlands, 1978.

52. UMS GmbH. KSAT: Operation Manual; Umwelt Monitoring System; GmbH: Munich, Germany, 2012.

(C) 2019 by the authors. Licensee MDPI, Basel, Switzerland. This article is an open access article distributed under the terms and conditions of the Creative Commons Attribution (CC BY) license (http://creativecommons.org/licenses/by/4.0/). 